\title{
Understanding Currents and Theories in Indian and African Postcolonial Literature: Themes, Tropes and Discourse in the Wider Context of Postcolonialism
}

\author{
SHIVANI EKKANATH
}

\begin{abstract}
The postcolonial narratives we see today are a study in contrast and tell a different tale from their colonial predecessors as minorities and individuals finally have found the voice and position to tell their stories. Histories written about our culture and societies have now found a new purpose and voice. The stories we have passed down from generation to generation through both oral and written histories, continue to morph and change with the tide of time as they re-centre our cultural narratives and shared experiences. As a result, the study of diaspora and transnationalism have altered the way in which we view identity in different forms of multimedia and literature. In this paper, the primary question which will be examined is, how and to what extent does Indian post-colonial literature figure in the formation of identity in contemporary art and literature in the context of ongoing postcolonial ideas and currents? by means of famous and notable postcolonial literary works and theories of Indian authors and theoreticians, with a special focus on the question and notion of identity. This paper works on drawing parallels between themes in Indian and African postcolonial literary works, especially themes such as power, hegemony, east meets west, among others. In this paper, European transnationalism will also be analysed as a case study to better understand postcolonialism in different contexts. The paper will seek to explore some of the gaps in the study of diasporic identity and postcolonial studies and explore some of the changes and key milestones in the evolution of the discourse over the decades.
\end{abstract}

Keywords: postcolonialism; transnationalism; identity; diaspora

\section{Introduction: Understanding Key Existing Literature}

Firstly, the exploration of this particular topic begs into question, what is the overall position of post-colonial literature in contemporary literary theory? Postcolonial literature can be defined as a broad approach towards understanding the complexities and hierarchies of different power relations in the political, social as well as the cultural realms. It usually encapsulates the work 
of different individuals across various fields from mostly colonised countries. Postcolonial literature served as an important complement to the wave of decolonisation that shook the modern world as previous former colonies were finally granted their rights freedom, autonomy or self-determination. Postcolonial literature for one, catalogues and in a way, even characterises this sweeping review and overview of our nations' art, history and politics. Storytelling and narratives continue to play a pivotal part in our daily lives, albeit in a strikingly different nature. Postcolonial literature, in its own way, seeks to explore and unravel a different narrative and interpretation of the past as well as the status quo. Nations and identities are able to re-analyse and re-claim their position in the world after the throes of the world wars and the tides of the decolonisation movement that shook many parts of Asia and Africa during that period of time. In India, in particular, post-colonial studies were a significant force in reframing the narrative and cementing a burgeoning and strong identity in a globalising country. Sangeet Kumar, a researcher from the University of Iowa, analyses the changes and dynamics of the cultural landscape in India, in particular looking at case studies in visual, musical and oral cultures, specifically highlighting the fact that India's morphing and new individualism still remains largely and closely knit to its strong relationship and ties with its colonial past in many ways.

Additionally, literary theory and other related cultural discourses have progressed further than the likes of Samuel Huntington's Clash of the Civilisations and primitive notions of Orientalism. Present-day post-colonial literature celebrates the further developments and new insights we continue to have in this field. The clashes between cultures are reaching a breaking point as we grapple with the ghosts of colonial pasts and precarious and uncertain futures. Indian experts and proponents of postcolonialism have brought a fresh perspective to the study of postcolonialism with their contributions to subalternism and subaltern studies.

For example, Divesh P. Chakravarthy's colonial historiography cites how subaltern studies offer a viable approach to interpreting and conceptualising post-colonial literature. Similarly, Gayatri Spivak defines the position and plight of the subaltern by accentuating the dominance of cultural imperialism and the dangers of strategic essentialism, which essentially silences and mutes the voice of the 'subaltern' in question, which is an important aspect often not as pronounced in the mainstream colonial discourse.

Interestingly, theoreticians like Homi K. Bhabha, have taken on a different approach by subverting what most postcolonial theorists posited and proposed. Instead, Bhabha views postcolonialism through the lens of cultural hybridity and perceives the evolution of the diasporic identity in the context 
of 'hybridisation.' This was a major re-conceptualisation of Edward Said's previous work on Orientalism, which describes the emergence of new cultural forms from multiculturalism. Homi Bhabha saw postcolonial forms of art and literature such as film as a narrative that constantly revisits our past as well as centres on our present, thereby re-defining cross-cultural relations and understandings. He introduced a so-called 'third or transnational space' which allows for the flourishing of an individualistic and autonomous 'hybrid' culture. Postcolonial literature also ushered in many fields and concepts within the realm of literary theory such as psychoanalysis, ecocriticism, poststructuralism and New-Criticism, to name a few. These literary concepts began to provide a strong foundation for some of the social commentary expressed in many works of postcolonial literature.

\section{Today's Postcolonial Indian Literature - Some Governing Themes and Examples}

For such an analysis, it is crucial to understand the different depictions of Indian identity through the years. Literature and film of the 1980s and 1990s are characterised more by the impacts of colonisation on India in an era after Gandhi, while the early 2000s to the present day explore Indian identity through the diasporic lens, as immigration from India to the United States began to increase. Indian literature cannot be representative of south Asian literature as a whole, but it is a viable case study in the examination and study of western imperialism given India's long-fought struggle with the British empire succeeding the revolt of 1857 to independence in the year 1947. Modernist departures in Indian writing, from their beginnings in the 1920s and 1930s, moved away from idealized visions of the human and dominant idioms of nationalist belonging. Anglo-Indian poetry was a response to the monotony and British traditions of pre-independence India. The 1930s also saw the emergence of Marxist literary efforts, with their insistent, critical foregrounding of social reality. Yet, the situation in India continues to be different, given the level of linguistic diversity in the country - a fact that continues to be significantly overlooked in Indian post-colonial discourse.

Moreover, the works of Arundhati Roy, Salman Rushdie, Jhumpa Lahiri and countless others have given postcolonial Indian literature a modern touch, as they explore and discuss complex issues like immigration, identity and the "East meets West" narrative. The notion of 'Indianness' is often simplified, as one often does not consider the number of cultural experiences, possibilities and identities, which remain at the centre of a diverse and pluralistic transnational experience. 
Lahiri, in particular, connects the personal losses suffered by her characters in the overall context of the loss one suffers when they begin to lose their sense of cultural rootedness. She explores tides like immigration, war, turmoil and love in her book Lowland. Lahiri begins with describing the tumultuous events following the partition of India and the exodus of Hindu and Muslim immigrants that followed, setting the mood and atmosphere of the political and social bedlam following India's independence from the British in 1947. Lahiri accentuates this fact in the first few pages of the novel, where she introduces the readers to the political landscape of the country and contrasts it with quiet Rhode Island, a place where the characters immigrate amid losing their loved ones and the political turmoil of their homes. It seems to come across as a more sombre and subdued and rather dismal backdrop that is a reflection of the pain and sorrow that Subhash and Gauri (the main characters of the story) experience after Udayan's death in all its bleakness. Therefore, the backdrop of the Naxalite struggle sets the stage for the impending losses suffered by each of the key characters and plays a pivotal role in bringing out the theme of loss in the novel. It underlines the fact that war and political change are a constant in the country and remain a prevalent part of an individual's life. Throughout the story, Lahiri continues to draw attention to details about the state of the political atmosphere in her efforts to heighten all that the beloved main characters sacrifice and losses during the Naxalite Movement.

But he was no longer in Tollygunge. He had stepped out of it as he had stepped so many mornings out of his dreams, its reality and its particular logic rendered meaningless in the light of day. The difference was so extreme that he could not accommodate the two places together in his mind. In this enormous new country, there seemed to be nowhere for the old to reside. There was nothing to link them; he was the sole link. Here life ceased to obstruct or assault him. Here was a place where humanity was not always pushing, rushing, running as if with a fire at its back. (Lahiri 2013: 34)

In this passage specifically, the clear juxtaposition between Bengali culture and that of the quiet isolation of Rhode Island in comparison makes for further evidence of the stark divide as well as the confusion brought about by the cultural limbo that remains so rife and enriched in immigrant stories such as Lowland. What is more, the story focuses on the richness and vibrancy of Bengali culture, establishing the cultural connection and profound sense of rootedness that our main characters continue to have with their native culture, which is largely denoted by the concept of hybridity and hybrid culture. Linguistic hybridity used in many works, in Lowland for example, further brings out this complex connection and fusion of cultures and understanding 
Understanding Currents and Theories in Indian and African Postcolonial Literature

different language patterns in the study of postcolonialism. This 'hybridity' is brought about by the somewhat partial adoption of western culture, which, in turn, is subsumed under the so-called 'third space', where individuals are able to engage and prosper in their environments. For Homi Bhabha, this is a representation of the 'liminal' or 'in-between' state that unravels hegemonic colonial narratives and helps redefine social structures and histories of many colonised countries across the world.

Additionally, Lahiri's Lowland may also be examined through the lens of female identity, by relying on the subaltern stance on female social standing in society, particularly drawing on intersectional feminist theory and Gayatri Spivak's renditions of the position of women in Indian society in relation to their western counterparts. This is conveyed through the depiction of the main female protagonist, Gauri and the sense of autonomy and ownership she has when it comes to defining her life and even making painful decisions that society may judge and ostracise her for.

In Lahiri's other novel, For the Namesake (2003), the themes of identity, for instance, shed light on a larger social commentary that brings the intertwining themes of immigration and cultural exchange into the fold. Many postcolonial themes, particularly family and relationships, remain a cornerstone of the representation of Indian diasporic identity as a manifestation of all these important lessons, mutual understandings and hardships. The main protagonist begins a journey in order to reclaim his identity and discern the true meaning of his roots, as described in the following excerpts from the novel.

They've learned their lesson after Gogol. They've learned that schools in America will ignore parents' instructions and register a child under his pet name. The only way to avoid such confusion, they have concluded, is to do away with the pet name altogether, as many of their Bengali friends have done. (Lahiri 20013: 56)

Not only does Gogol Ganguli have a pet name turned good name, but also a last name turned first name. And so it occurs to him that no one he knows in the world, in Russia or India or America or anywhere, shares his name. Not even the source of his namesake. (Lahiri 2003: 26)

Moreover, the realities of generational conflict, the ambiguities and complexities of identity crisis and cultural isolation are poignantly represented in the book. It is very rife with literary symbolism and techniques, especially the metaphor of movement, travel and naming.

Lahiri thus explores the harmony between western and Indian culture through her characterisation of immigrants. Such stories of immigrant children 
do not put the east and west on opposing sides, but rather seek to form a nexus and connection between them, so that they may coexist in harmony as well as gain an appreciation and admiration for each other. Even though immigrant stories such as For the Namesake often cater to the formation and building of Indian national identity, the Non-Resident of India (NRI) became a symbol of identity construction beyond the confines of the nation and its traditions, especially with its realist themes and depiction of western modernity and its clash with the understanding of traditional Indian identity and notion of 'Indianness'. At the same time, it also draws on Homi Bhabha's understanding of the processes and articulations of cultural differences in a western society where the diasporic identity and the notion of 'Indianness' is tested. As immigrants, Gogol's parents seek to create a hybrid environment for their son through a mix of both Bengali as well as American culture.

In a similar manner, Yann Martel's best-selling novel Life of Pi (2001) explores the concept of fluid identity through the concept of religion. The main character, Piscine, is what Bhabha would call a 'hybrid' character as he embraces a number of religions through the course of his life and challenges the East and West narrative. The protagonist neither sides with the 'coloniser' or the 'colonised', but is somewhere 'in between.' He possesses a certain agency of his own and refuses to adhere to what he later sees as the social constructs and binaries of society, religion and culture.

A germ of religious exaltation, no bigger than a mustard seed, was sown in me and left to germinate. It has never stopped growing since that day. (Martel 2002: 46)

The book challenges the model of the nation-state and seeks to delink Hinduism from the notion of 'Indianness' as it becomes the central aspect of Pi's identity. It remains a true representation of the interaction the main character has in the so-called 'transnational space' back in his home in Pondicherry as well as his future life in Toronto. The use of symbolism and other associated literary devices in the book are largely focused on the metaphor of the ocean and water to hint at the character's sense of loss, isolation and uprootedness, as he is not 'anchored' to any location and is able to freely think and believe as he pleases.

Salman Rushdie takes on a different approach in his novel Midnight's Children (1981) as he tries to convey a postcolonial critique of the Indian Freedom Struggle of 1947. Rushdie uses magical realism as a major technique to help us through a unique journey of historical imagination. His chief protagonist, Salim Sinnai, like the rest of the characters in the novel, belongs 
to an important group of children who were born at the stroke of midnight on 15th August 1947. The book brings together many pertinent concepts in postcolonial theory such as miscegenation, mimicry and specifically hybridity, owing to Salim's own mixed heritage and background. Rushdie, in his own way, brings together and fuses complex binaries in the postcolonial retelling of India's freedom movement such as the struggle between east and west as well as the relationship between the colonised and the colonisers. Most importantly, Rushdie perceives the freedom struggle to be a complex and harmonious resistance uniting different identities across the Indian subcontinent. In the following passage, the importance of memory and national identity is very profound as Salim deciphers how he understands his own memories and thoughts. He is able to extract his own version of the truth through his own patterns and experiences, which in turn, helps him understand the history of his own country and his own significance and position within that context.

I told you the truth," I say yet again, “Memory's truth, because memory has its own special kind. It selects, eliminates, alters, exaggerates, minimizes, glorifies, and vilifies also; but in the end it creates its own reality, its heterogeneous but usually coherent versions of events; and no sane human being ever trusts someone else's version more than his own. (Rushdie 1981: 225)

The freedom movement and its history is told beautifully through the technique of magical realism, as it portrays the characters as larger than life figures and puts the colonised in a position of higher authority and power, as their magical powers serve as a crucial and necessary hyperbole that enforces their strength and autonomy in the face of the dangerous and seismic social and political upheavals occurring in post-British India. Magical realism also remains an important and significant literary device that features in many postcolonial literary works across Asia and the Middle East. It is an excellent narrative framing device that helps tell stories from some of the most troubled areas of the world.

\section{Comparing Postcolonialism and Associated Themes: \\ A Case Study of African Postcolonial Literature and Discourse}

A common trope that is seen in Indian postcolonial literature is the omnipresent important narratives of national identity and culture. This is mainly brought about by the re-orientation of the lives of colonised communities and individuals. 
Not unlike Indian postcolonial literature, African postcolonial works have also experienced various wavelengths of scholarly debates and have also discussed themes revolving around identity, nation-building and shared history. The very foundations of the idea of 'empire' began to steadily crumble as European civilisations started to disintegrate due to the ever-slackening grip of its colonial legacies. The resistance of local cultures to the domination and perversion of western colonial oppression was an essential aspect in many works that were written during this period of time.

Modern postcolonial African narratives deal a lot with reclaiming and redefining African identity in the midst of seismic modern-day changes occurring on the continent. Both African and Indian postcolonial literature analyse the common 'anti-conquest narrative' where the locals and indigenous people are regarded as the victims of westernisation and colonisation rather than the commonly held notion of the 'lazy native.' Neil Lazarus suggests that the colonial enterprise failed in its desire to erase the African past, having never succeeded in changing the path of African history or the strength and prevalence of African cultures.

The idea of Pan-Africanism remains a very common trope in many postcolonial works, especially considering the effects of decolonisation on African nations. Pan-Africanism grew to become a movement that strengthened and encouraged deeper solidarity and bonds between ethnic and diasporic African groups. In Matigari, a work which will be explored later, the main character reflects, 'There are two types of people in this country. There are those who sell out, and those who are patriots" (Wa Thiongo'o 1986: 126). As a result, the debate over 'African modernity' became a pivotal theme in African postcolonialism, in particularly as people and communities sought to build their own identities and make sense of the seismic changes occurring in their sociopolitical environments. The African modernity that James Ferguson analyses was a preoccupation for certain groups in colonial and postcolonial African societies: political leaders, union leaders, students, specialists as well as workers in economic development. However, the historian Joseph Ki-Zerbo warns against the assimilation and appropriation of the history and culture of others because it cannot provide any guarantee of success in terms of development and modernisation.

They seek to shed light on the hardships and plight of these people at the hands of their European colonisers and rely on their storytelling techniques to capture these crucial cultural elements. The Nigerian author Chinua Achebe, in particular, blends the local traditional storytelling with contemporary features of literary aestheticism. He keeps the African literary tradition alive by combining various elements such as African poetry and literary aesthetics, 
Understanding Currents and Theories in Indian and African Postcolonial Literature

including visual images of flora, fauna and other important allegorical representations linked to nature. From the beginning of the novel the author presents the significant divide between the Igbo tribe and their European invaders as expressed in the following line from the novel. The Igbo tribe are seen to be culturally hidebound in their thinking and preservation of their histories.

Among the Igbo the art of conversation is regarded very highly, and proverbs are the palm-oil with which words are eaten. (Achebe 1958:4)

According to Bill Ashcroft, Gareth Griffiths and Helen Tiffin, African literature may be analysed and appraised as they 'intersect in many ways', as contemporary literary works and theories reflect on concepts such as postmodernism, Marxism, feminism, ecocriticism, as well as psychoanalysis. These concepts continue to be recurring features in the works of Achebe, Ngugi Wa Thiong'o, Frantz Fanon, Buchi Emecheta, Dennis Brutus, and many others.

The philosopher Antonio Gramsci defined power in his theory of cultural hegemony by citing how the ruling classes possessed their strength owing to power over ideology, which is a concept that is heavily discussed in postcolonial work. Apart from the shadows of western imperialism that play a consistent role in many postcolonial works, literature also re-interprets other facets of postcolonial literary finesse and brings more marginalised voices to the fold. The postcolonial identity in both these instances seems to be largely formed by loss, national trauma and identity crisis that colonised countries and identities have suffered during the period of colonisation. These threads perform a similar framing structure for the collective works of many south Asian and African writers. A Foucauldian approach enables us to view analyse the indomitable force of power or the upper hand that European colonisers possessed over language and first and foremost, knowledge, while invariably made them possess the power over the colonised.

Many African writers like Ngugi Wa Thiongo and Chinua Achebe depicted the power and dominance of Christianity, alluding to themes such as native culture and religion in their writing. For instance, the indigenous lives of the Igbos are challenged by the growing spread and dominance of Christianity in Things Fall Apart (1958) and the tribe's folk see the impending wave of Christianity as an intrusion into their way of life. Although dominated by their male counterparts, Things Fall Apart also depicts the character arcs of strong women with a great amount of storytelling flair, specifically characters like Enzima who further represent the change in gender roles and position of women in society. 
Similarly, Ngugi himself harboured a great distaste for any elements of colonialist ideas which then led him to abandon his Christian name in exchange for a name that represented what he believed were his roots and culture. In their works, Chinua Achebe's Okonkwo and Nguig's Matigari are seen as the bulwarks that stand between foreign invaders and their communities. Matigari (1990) tells the story of a man who goes to mete out justice for his people who have been oppressed by foreign interference and the impacts of modernisation. $\mathrm{He}$ is the very representation of the anti-colonial nihilistic hero, given his name when translated means 'the patriots who survived the bullets.'

Similarly, Achebe shows how the native Nigerian tribe of Umuofia struggled due to the arrival of Christian missionaries. Upon closer reflection, the phrase in Achebe's work, "You see I built the house with my own hands, but Settler Williams slept in it and I would sleep outside the veranda", characterises African attitudes towards the colonial struggle to a great extent as they saw foreign interference as a gross invasion into their way of life (Achebe 1958: 21). Yet, the story also sheds light on the divided society that the tribes inhabited where they brought on their own downfall by cementing fractures due to their grievances, personal and petty differences. Though formidable and strong, Okonkwo's pride and hidebound penchant for tradition is his hamartia and inevitably leads to his downfall, as he is unable to unite the tribe and commits suicide at the end of the novel as a result.

\section{Understanding the Gaps in Identity Construction: Critics of Scholarly Debates and Postcolonial Discourse}

Despite the fact that diasporic literature and art have proven to be rather emancipatory for many hidden aspects of Indian identity, postcolonial discourse in literature, cinema and art still continue to be linked with the foundation and governing concept of 'hybrid' cultural production, as posited by Homi Bhabha. Amar Acheraiou, in turn, criticises Bhabha's mostly syncretic view and emphasises the racial undertones that still continue to exist in films and other forms of artistic discourse. Often, the understanding of hybridity and its associated transcultural form are embedded in the thinking and comprehension of the social and political contexts which they are based on. According to Robert Young, the term and notion of hybridity grew to become inextricably linked with 'colonialist discourse of racism.' In a sense, rather than undoing and going past the confines of the existing essentialist frameworks, hybridity may have, in fact, achieved the opposite by alluding to and recalling 
Understanding Currents and Theories in Indian and African Postcolonial Literature

essentialist elements. As a result, the 'Anti-Hybridity Backlash' became a very debated academic topic (Pieterse 2001).

In the past, critics like Chandra Talpade Mohanty, Benita Parry and Aijaz Ahmad have noted that colonial discourse theory and the hybridity analysis have often neglected to encompass specific elements about local culture and differences, thereby resulting in a certain degree of de-historicisation of cultures, specifically their rich linguistic, spatial and geographic aspects. In the Handbook of Global Communication and Media Ethics, Robertson states that the notion of globalisation is important in order to understand international dynamics, positing that it "captures the dynamics of the local in the global and the global in the local," as a way for media and film scholars to understand representation in the realm of local contexts and key distinct groups and communities. Recalling the case study of African postcolonialism and also alluding to the generalisation of postcolonial identity given India's cultural and linguistic hybridity, Eric Anchimbe proposes an important linguistic research strategy to study the diversity and languages of postcolonial people. The strategy reiterates the necessity of a more community-centred approach in the study of multilingualism and culture.

Additionally, the model minority is a recurring trope that often tends to overly accent the notion of the American Dream to a point where it overrides the narratives and stories of the characters in postcolonial literary works, especially books that deal with topics and themes like diaspora and immigration. Rather than expressing individualism and their own sense of identity and belonging, the immigration story is almost muted in the wake of the overpowering American Dream. Indian identity is seen in an inferior light and submissive role in comparison to the dominance of overarching struggle and effort to achieve the so-called 'American Dream.' Often we see the 'East' in conflict with the 'West' as they are expressed as concepts that are almost antagonistic in nature.

\section{Understanding European Links: European Diasporic and Transnational Cinema}

European diasporic and transnational cinema, in particular, helps us to explore and identify another interpretation of postcolonial ideas and themes in contemporary forms of art and discourse. It helps us to recognise the impact of globalisation on postcolonial ideas and movements and the importance of the flourishing concept of 'world literature', along with the revitalisation of the ideas of 'imagined communities.' It helps to bring concepts like transnational 
migration, identity and social transformation to greater prominence. After the decolonisation movement that shook western countries during the course of the war, another seismic socio-economic change that ushered its way in was immigration, especially from North Africa and the Middle East. The common notion of borders continued to be challenged as a greater influx of immigrants continued to arrive in Europe. However, these changes also brought with them turbulent undercurrents that took on the form of racial prejudice and xenophobia, which unfortunately remain prevalent today. After reviewing the different tides of postcolonial literature in the following two contexts, similar parallels may be drawn to the European narrative as well. Europe's own postcolonial literary approach has taken a melange of different forms, from migrant literature to the exploration of transnationalism and identity in art and film.

Transnationalism as such refers to the film-making of any community who moves away from their homeland to settle in another country. The dawn of transnational and diasporic cinema witnessed a retelling and transformation of the likes of third world cinema or national cinema and acted as a suitable 'third way' to reformulate and reinterpret previously held narratives. Diasporic cinema was seen as a part of 'cultural-demythologisation' (Aksoy and Robins 2003). The complexities of these stories and identity constructions are highlighted in the book The Skin of the Film by Laura Marks where she speaks about how diasporic cinema goes beyond the confines of just one culture as it comes to represent a transient identity of sorts that 'mediates in at least two directions'. Other understandings of this term such as those of Robin Cohen try to dissect the convoluted nature and meaning of 'diaspora' as being a fracture of 'dislocation in this postcolonial sense'. Popular Indian cinema also continues to witness the 'transnational turn', owing to the growing dominance of Indian representation in Western cinema, Hollywood and media.

Moreover, Meena Alexander has said that diasporic writing, in its essence, is all about 'writing in search of a homeland', as one is caught between the tug of war of one or more identities owing to a certain sense of alienation they encounter, coupled with the nostalgia of memories. This remains specifically notable while analysing postcolonial trends in the European setting.

For example, movies by directors like Fatih Akin have been groundbreaking in chronicling the experiences of Turkish immigrants in European countries like Germany. His film, The Edge of Heaven, in particular, is a testament to the endurance and struggle of the Turkish identity in the face of the turbulent political and social environment of Europe. However, in film studies today, hybridity is still often studied within the general context and 
Understanding Currents and Theories in Indian and African Postcolonial Literature

understandings of the Hollywood model. Western and European films remain the benchmark for the representation of the Indian diasporic lens.

\section{Criticisms of Postcolonialism}

Many have come to question the very validity of postcolonialism in today's context, as it serves to revitalise eurocentrism, especially when considering concepts like Homi Bhabha's hybridity and the ideas of centre and periphery. As a result, postcolonialism is once again perceived as a blanket and essentialised term. Marxist ideologues such as Aijaz Ahmad and other Marxist critics deem postcolonialism largely deficient in important concepts such as political economy and numerous other contradictions and inaccuracies. Theorists like Spivak pose real-world implications that now seem to go beyond the confines of her literary work, especially due to her Marxist and anti-Eurocentric approach to postcolonial feminism. Furthermore, very few postcolonial works focus on the 'anti-conquest narrative' and amass internal and external displacements that colonised countries and individuals faced. Modern postcolonial novels, which have remained the focus of the discussion in this paper, concentrate more on chronicling and telling the immigrant story. African postcolonial works, particularly Things Fall Apart and Matigari seem to address and emphasise the 'anti-conquest narrative' to a much greater degree. Mary Louise Pratt explains how the European explorer often struggles in foreign lands, which often tends to further exacerbate and underline the stark lines of cultural division and otherisation.

To offer a critique of the very notion and concept of identity itself, despite all the debate and literature on the subject, it remains difficult to define a film on a given definition. The very notion of a concrete identity is in itself misleading given the fact that diasporic identity has so many complex layers and questions, with a great many distinctions and elements. The holistic representation can only be judged for its context and time as it is constantly evolving and subject to various scholarly and cinematic debates. Though Indian identity cannot be entirely representative of the complete scope of south Asian identity, it offers much room for introspection owing to some of the palpable developments and successes in greater representation and portrayal they have achieved not only in the realm of literature, but other forms of art and contemporary artistic discourse. 


\title{
Conclusion
}

Ultimately, post-colonial literature offers us another interpretation and reexamination of traditionalist approaches and Eurocentric views that we have internalised into our shared knowledge, ideas, thoughts, beliefs, and ideologies. Our worldviews and outlooks on concepts like modernism, art and culture have been altered by this new way of thinking. Further developments within the field of literary theory will perhaps yield new phases of progress that will bridge existing gaps. Postcolonial art teaches us that times have changed and that history is no longer simply written by the victors, but those who are committed to the documentation, truth and preservation of histories. At this particular juncture, many countries still bear the remnants of residual colonisation as we seek to acknowledge our colonial past and carve out our new identities. Though it can be argued that these 'remains' seek to glorify years of oppressive social, economic and political hegemony, it is a way of countless countries to not exactly accept, but also recognise and reconcile the different fragments in the history of their national and social fabric.

Returning to the inspiration behind Rushdie's quote in the abstract, the very nature and features, and objectives of postcolonial discourse primarily aim at continuing to retell and recentre stories of colonised individuals and nations. Nation-building may be perceived as a social construction of our identities. It continues to be a transient process that is documented and heavily critiqued along within our intellectual histories. Rather than studying post-modernist history as a field, it is necessary to analyse each of them through a separate lens, as different cultures and communities have different stories and circumstances.

\author{
Shivani Ekkanath \\ shivani.ekkanath@sciencespo.fr
}

\section{Bibliography}

Achebe, C. 1958. Things Fall Apart. Nigeria: Penguin.

Aksoy, A., Robins, K. 1997. Peripheral Vision: Cultural Industries and Cultural Identities in Turkey. - Environment and Planning A: Economy and Space, 29 (11), 1937-1952. https://doi.org/10.1068\%2Fa291937.

Fackler M., Fortner, R. S., eds. 2011. The Handbook of Global Communication and Media Ethics. Hoboken, New Jersey: Wiley-Blackwell.

Ferguson, M. 1993. Review [of Imperial Eyes: Travel Writing and Transculturation by Mary Louise Pratt]. - Eighteenth-Century Studies, 26 (3), 481-484. https://doi. $\operatorname{org} / 10.2307 / 2739415$ 
Understanding Currents and Theories in Indian and African Postcolonial Literature

Kalua, F. 2009. Homi Bhabha's Third Space and African identity. - Journal of African Cultural Studies, 21 (1), 23-32. https://doi.org/10.1080/13696810902986417

Kumar, S. 2010. Postcolonial Identity in a Globalising India: Case Studies in Visual, Musical and Oral Culture. [Doctoral thesis.] Iowa City: University of Iowa, Iowa Research Online, https://ir.uiowa.edu/etd/3328/ (21.11.2020).

Lahiri, J. 2013. The Lowland. New York: Vintage.

Lazarus, N. 1993. Postcolonialism and the Dilemma of Nationalism: Aijaz Ahmad's Critique of Third-Worldism. - Diaspora. A Journal of Transnational Studies, 373400. https://doi.org/10.1353/dsp.1993.0000

Lazarus, N. 2011. The Postcolonial Unconscious. Cambridge: Cambridge University Press.

Marks, L. 2000. The Skin of the Film: Intercultural Cinema, Embodiment, and the Senses. Durham and London: Duke University Press.

Martel, Y. 2002. Life of Pi. Edinburgh: Canongate Books.

Morris, R. C., Spivak, G. C. 2010. Can the Subaltern Speak?: Reflections on the History of an Idea. New York: Columbia University Press.

Pieterse, J. N. 2001. Hybridity, So What? - Theory, Culture \& Society, 18 (2-3), 219245. https://doi.org/10.1177/026327640101800211

Rushdie, S. 1981. Midnight's Children. London: Vintage.

Shankar, L. D. 2001. Postcolonial Diasporics "Writing in Search of a Homeland": Meena Alexander's Manhattan music, fault lines, and the shock of arrival. - Lit: Literature Interpretation Theory, 12 (3), 285-312. https://doi.org/10.1080/ 10436920108580293

Thiongo, N. wa. 1986. Matigari. Oxford: Heinemann. 